\title{
A Teacher's Experience in Teaching with Student Teams-Achievement Division (STAD) Technique
}

\author{
Yunisrina Qismullah Yusuf \\ Dr., Lecturer, University of Syiah Kuala, Banda Aceh, Indonesia. yunisrina@ gmail.com \\ Yuliana Natsir \\ M.A., Lecturer, University of Syiah Kuala, Indonesia.dekya13@yahoo.com \\ Lutfia Hanum \\ B.Ed., University of Syiah Kuala, Banda Aceh, Indonesia.h_lutfia@ymail.com
}

This study looks at Student Teams-Achievement Division (STAD) implementation from a qualitative approach by observing and interviewing a teacher who successfully improved his EFL students' reading achievement with this technique. The procedures by Shaaban and Ghaith (2005) were the foundation for STAD implementation, and an interview was done to exhibit the teacher's stance on the use of STAD. Based on our observation during his teaching in a reading class by implementing STAD, it was found that he did not implement one procedure of this technique, which was assigning a role for each member of the groups. From the interview, he informed that he did not conduct this procedure because he believed that assigning roles should be entrusted to the students to increase their sense of responsibility towards the accomplishment of the group task. Furthermore, he also modified five procedures from nine procedures of STAD proposed by Shaaban and Ghaith (2005). The modified procedures were related to the way the quiz was given to students, providing printed answer key, ways of correcting the student's quiz, providing the team recognition form, and ways of recognizing the students' achievement. He informed that they were modified due to the efficacy of students, time limitation and the school's financial problem.

Key Words: student teams-achievement division, procedures of STAD, group work, EFL reading class, teacher's stance

\section{INTRODUCTION}

In Indonesia, English is taught as a foreign language starting in the junior high school according to its newest 2013 Curriculum guide. The basic language skills such as listening, speaking, reading and writing are taught. In reading skill for junior high school students, the standard competence expected to be achieved is to understand meanings of very simple short functional written discourses related to their environment. However, most students in Aceh province still face difficulty in achieving this learning goal, especially when they are to learn individually in the classroom in completing the reading

DOI: $10.12973 / \mathrm{iji} .2015 .828 \mathrm{a}$ 
tasks. This drawback is a dilemma faced by students in Indonesia in general (see Nurhanifah, 2012).

Hence, among the ways to improve the students' individual learning in the classroom is by working in groups. One of the well-known techniques used in teaching reading that promotes group work is Student Teams-Achievement Division (STAD), developed by Slavin in 1994. Many studies have been conducted to improve the students English reading skills by implementing STAD, thus, most of these studies were conducted in the nature of experimental teaching. Some examples are those carried out on EFL learners such as by Cahyani (2013) to junior high school students in Indonesia, Warawudhi (2012) to university students in Thailand, and Alijanian (2012) to junior high school students in Iran. The findings from their studies showed that the teaching of reading to students by using STAD in the experimental classes were more effective than the control classes that were taught by using non-STAD techniques. This was concluded based on the students' post-test scores which were better than the pre-test scores after implementing STAD in the teaching and learning process.

Consequently, we are further interested to look into the implementation of STAD from another point of view, that is from a qualitative approach by observing and interviewing a teacher who has successfully taught and improved his students' reading skill from group work with this technique in an EFL classroom. We believe that to determine a successful teaching and learning process is not merely through the result of students' high scores, but it is also influenced by the teacher's belief and stance on the methods and techniques he or she uses in the classroom. This is as argued by Kuzborska (2011, p. 102) that "language teachers' beliefs and understandings of teaching as well as learning play an important role in their classroom practices and in their professional growth". Therefore, an applicable research by looking at STAD implementation from a teacher's standpoint is viewed necessary to explore because his or her expectations about language learning become the underpinnings for his or her choice of certain methods to language instruction.

For the reasons above, we were interested to observe the teacher's teaching and learning process of reading by using STAD to his second grade students of junior high school. We also wanted to know his stance on his implementation of STAD in teaching reading. Subsequently, the research questions in this study are formulated as follow: (1) How does the English teacher implement STAD technique in teaching reading? (2) What is his stance on the use of STAD in teaching reading?

Hence, it is expected that this article can be beneficial to English teachers, especially those who teach in countries that treat English as a foreign language. It is hoped that this study can foster further understanding and consideration on the use of STAD as one of the techniques to assist EFL students to improve reading skill in classroom learning.

\section{LITERATURE REVIEW}

\section{Reading Skill and Cooperative Learning}

Woolley (2011) further stated that reading comprehension is the process of making meaning from text; hence it has the goal to gain an overall understanding of what is 
described in the text rather than to obtain meaning from isolated words or sentences. Therefore, this skill is an effort to understand a text, to expand the reader's knowledge and information. Its essential goal is to comprehend the content of message in the written text.

To teach reading in an EFL class, the teacher should not only have knowledge on the reading subject but also on the appropriate technique needed by the students to achieve the teaching and learning goals. When individual learning does not enhance the students to accomplish the anticipated results, teachers must make decisions and move on to a technique where teamwork may facilitate reinforcement for the weak individual learners. In view of that, cooperative learning (CL) is a method that offers ways to enhance learning and increasing academic achievement by means of group work in the process (Slavin, 2010). For EFL learners, Sousa (2005) argued that CL is a constructive method for students in making the transition to read in English because the method provides many opportunities for students to work together and share understandings. Hence, this method can provide solutions to teaching problems because students' with high achievement and those with low achievement interact with each other to complete tasks in group work, which can assist the process of language learning to gain academic achievement and improve social skills (Wang, 2007). Accordingly, the roles of teachers in this method are generally to facilitate, monitor students' engagement with process, or clarify information, rather than merely providing information or instruction (Kessler, 1992).

When working collaboratively, two aspects that are essential in improving affective outcomes are group goals and individual accountability (Slavin, 2010). These two aspects trigger students to impart their interest in the learning needs of themselves and also of other students. Consequently, two general techniques in the CL method adaptable to most students at any age in any subjects being taught are Student Team Achievement Division (STAD) and Teams Game Tournament (TGT) (Slavin, 2010). In these techniques, students are assigned into heterogeneous groups or teams. They are mixed in performance level, sex and ethnicity. They complete a task by working together and ensuring that all team members have mastered the lesson (Slavin, 2010).

Compared to individual learning, cooperative learning have thus been found to lead learners to higher levels of thinking from sharing ideas and seeking for solutions with peers through group work or "process gain" (Roger and Johnson, 1994), and a better transfer of knowledge through "group-to-individual transfer" (Roger and Johnson, 1994). Since this study focuses on the implementation of STAD, therefore the following section focuses on the explanation of this technique.

\section{Student Team Achievement Division (STAD)}

According to Gross (1991, p. 56), "STAD is a technique in the teaching learning process that is effective to increase students motivation and enthusiasm, and it can develop their responsibility in their own group". It is considered a good model because as one the CL techniques, it can raise students' motivation in learning by exchanging and sharing 
information, reinforcing each other, giving feedback and having the responsibility for their tasks in group work.

Slavin (1995), mentioned that STAD have five major components, namely class presentation, team study, quizzes, individual improving scores, and team recognition. In class presentation, the teacher usually introduces the material in a class presentation and students must pay careful attention to his/her presentation, because if they understand the material, it will help them in quizzes and their quizzes scores determine their team score. In team study, each team is composed of four to five students from different level of performance, gender, and ethnicity. Each team must conduct group discussion, pair check, and work together until each member is sure that everyone in the team can achieve high grades for the quiz. When they have questions, they should ask their friend(s) first before asking the teacher. This process further promotes responsibility in team work. In quizzes, the aim of individual quiz is to measure the students' understanding of the lesson; therefore, when doing quizzes, they are not allowed to help each other. The students correct their quizzes using an answer key to determine their improvement points according to the following guidelines adapted from Slavin (1995, p. $80)$.

Table 1: Guidelines to determine the improvement points

\begin{tabular}{ll}
\hline Quiz Score & Improvement points \\
\hline More than 10 points below base score & 0 points \\
\hline 0 points below to 1 point above base score & 10 points \\
\hline Base score to 10 points above base score & 20 points \\
\hline More than 10 points above base score & 30 points \\
\hline Perfect paper irrespective of base score & 30 points \\
\hline
\end{tabular}

In individual improvement scores, the teacher reviews the lesson and the students continue team practice on the reviews by the teacher. The students must ensure every teammate knows the answer. In this way, they are given an opportunity on their performance goal which can be attained if they work harder on performing better than their previous performances so that any student can contribute maximum points to their team. Lastly, in team recognition, the team which has the highest score will earn certificates or other rewards from the teacher based on each team's improvement score. The improvement score is collected from individual scores of the group after the quizzes. Teachers may see the following criteria to determine team awards such as in Table 2.

Table 2: Team recognition forms

\begin{tabular}{ll}
\hline Team average & Award \\
\hline $15-19$ points & Good team \\
\hline $20-24$ points & Great team \\
\hline $25-30$ points & Super team \\
\hline
\end{tabular}

To conclude, STAD is one of the CL techniques which assign students into small heterogeneous teams in which each team consist of four to five members from different performance level, gender, and ethnicity. They are expected to help each other until all members of the group understand the subject because the overall team score is summed up from the group members' scores. 


\section{METHOD}

The method used in this research is qualitative. It draws on the data collected by the researcher in the form of texts and descriptions of behaviors and actions or practices (Burns, 1999). Accordingly, we observed and described the implementation of STAD technique in a meeting of a reading class ( 2 x 45 minutes $)$ as implemented by our respondent, the English teacher (coded as ETR), to 24 second grade students of a junior high school in Banda Aceh, Indonesia. An observation was done in order to know the productivity and implementation of STAD by ETR in improving students' reading skill. Afterwards, we interviewed him to find out his stance on the use of STAD in his teaching. A consent letter was signed by ETR before the observation and interview were conducted.

ETR was chosen as our respondent because we found him to be rather thriving in improving his students' average reading scores from below the standard minimum achievement criteria of the school (which was 66) to above it after teaching reading with STAD (which was 70).

\section{Research instruments}

There were 2 kinds of instruments used in this study: an observation sheet and interview questions. The observation sheet was used to observe, document and interpret the process of teaching and learning of reading by the teacher in using STAD. Accordingly, we used an observation sheet to guide us in carrying out this method. The items of observation sheet were created based on the theory by Shaaban and Ghaith (2005) to discern whether ETR had taught as the experts suggested or there was more activities or improvement from him.

ETR was further recoded with an interview by using semi structured questions in Bahasa Indonesia, which was later transcribed and translated into English for this paper. According to Burns (1999, p. 119), individual interviews enables a researcher "to follow up in more detail particular issues which have been identified, or insights or observations already made but not fully reflected upon". In consequence, we conducted an interview with ETR after participant observation was done in the classroom. The questions we asked were related to the efficacy of using STAD in the classroom, such as his reasons for using this technique, the benefits, and obstacles in implementing it and how to resolve them. In view of that, Ningsih and Fata $(2015$, p. 69) asserted that "teachers' beliefs depend on what they trust should be real and worthy" because this will guide them in making decisions, promoting attitudes, and building interaction with their students. Therefore, reflecting on ETR's stance on his choice to implement STAD to improve his students' reading skill is important to draw upon to exemplify his accomplishment in using STAD technique to teach reading.

\section{RESULTS}

\section{Observation}

From our observation, ETR started the teaching process by greeting the students with "Good morning my students. How are you today? What are your feelings today? Are you happy? Did you study last night? Are you ready to learn?" After greeting the students and having them answered his questions, he checked their attendance list, and 
informed them that they were going to learn about narrative text that day. He wrote "Narrative text" on the white board then asked them some questions related to the topic in which some of the students responded. Next, he presented the material by explaining about narrative text and also wrote some points on the white board about the text.

After that, he asked the students to sit into groups in which he had formed for them. ETR had selected members for the groups before class begin. He believed that heterogeneous groups work efficiently in accomplishing the learning goals if teachers know the ability of their students in order to group them successfully (see E2 or excerpt number 2 in the following interview section). Correspondingly, each group consisted of four members (of boys and girls) with high, average and low level achievement students distributed equally in each group. Subsequently, six groups were formed. After they sat in their groups, he gave one paper for each student. The paper was an example of a narrative text and the groups' worksheet or task. The worksheet contained five questions that they were to answer based on the text.

Afterwards, ETR explained the things that the students should do in their group. He gave the instructions orally. He asked them to do the task together in their own group and reminded them that their task was not only to answer the questions together but each of them should also understand the concept. He also said that they were to consult their friends first should they face problems before consulting him. They were to assist each other until all of their teammates understood the task (or known as group goals). He also informed them about the individual quizzes that he was going to give later on after the group work to get them prepared for it (or known as individual accountability).

During group work, the students conducted discussion, shared ideas, helped each other, and took turns in doing the task. Through this activity, they used the dictionary together to look up for meanings of certain words in the narrative text. This condition is believed to assist their vocabulary development while accomplishing the worksheet (this situation is known as process gain). ETR monitored the class by walking from one group to another. There were times when the class got loud and seemed out of control, and he would repeatedly remind the students to speak softly. Some students were heard to use Bahasa Indonesia quite often. However, when ETR approached them, they switched to English. He worked as a co-participant in each group for most of the time but would step out whenever required, managed the class if it got out of hand (e.g. noisy) and gave new instructions when necessary.

After the students finished accomplishing the worksheet with their group, ETR gave an answer sheet to each group and asked them to check their work. As soon as they finished discussing the worksheet with the answer key, he then gave them individual quizzes. Some moving around the classroom was required as the students were to sit and work individually and were prohibited to cheat or help each other. He read ten questions aloud and they wrote down the answers directly on their paper. After the individual quiz was done, he asked them to change their answer sheet with their nearest friend, and then, he wrote all the answers on the white board and asked them to give 10 points for each correct answer (this situation is known as group-to-individual transfer). 
Afterwards, ETR asked the students to form back their groups. While they moved around to sit in their groups, he gave the score of each group by adding up the members' individual quiz scores. When they were settled in their groups, he informed each groups' average score and wrote them on the white board. For their average score, group A got 80 , group B got 70, group C got 90, group D got 80 , and group E got 80 . He praised them for achieving the scores above the KKM, which were 70. Group $\mathrm{C}$ was rewarded as the super team because it obtained the highest score compared to the others. Group A, D, and E were rewarded as the great teams, and Group B was rewarded as the good team. The whole class gave applause for their hard work. At the end of teaching learning process, he gave high appreciation towards their participation and thanked them on their enthusiasm in doing the activity. He finally ended the lesson by reviewing some vocabulary based on the text and reminded them to remember the words.

Linking the teaching and learning process to our observation sheet, it was found that there were nine main points that were divided into seventeen sub points. It should be noted that Borich (2007) also proposed similar procedures as Shaaban and Ghaith (2005) except for one practice; that is the teacher gives the answer sheet or key (see point $1 \mathrm{~d}$ in Table 3 ) after the students work together in accomplishing the worksheet, so, they use the worksheet answer key to correct their work. On the other hand, Borich (2007) recommended that the answer sheet is given before the group members begin working together, so, the students immediately can accomplish the worksheet with the answer key without completing the worksheet first. Therefore, we can see that the procedure provided by Shaaban and Ghaith (2005) offered students the opportunity to practice and initially work together to obtain the answers before the answer sheet is given. Whilst Borich (2007) offered a chance to widen the students' discussion on the answer sheet initially given, should they have doubts and questions on the answers.

To provide a more detailed description on the results of our observation, Table 3 displays that ETR did not implement one procedure of STAD as suggested by Shaaban and Ghaith (2005) and five procedures with few modifications.

Table 3: Result of observation

\begin{tabular}{|c|c|c|c|}
\hline No & Activities & $Y E S$ & $\mathrm{NO}$ \\
\hline 1. & $\begin{array}{l}\text { The teacher prepares the material: } \\
\text { (a) A teaching point about lesson that will be taught by the teacher } \\
\text { (b) Worksheets: one copy per students' group } \\
\text { (c) A quiz: one copy for each student } \\
\text { (d) An answer key: one copy per group } \\
\text { (e) Team recognition form }\end{array}$ & $\begin{array}{l}\sqrt{ } \\
\sqrt{ } \\
\sqrt{*} \\
\sqrt{*} \\
\sqrt{*}\end{array}$ & \\
\hline 2. & The teacher forms heterogeneous which consist 4 or 5 members. & $\sqrt{ }$ & \\
\hline 3. & $\begin{array}{l}\text { The teacher assigns a role for each member of the groups. The following } \\
\text { roles may be considered: } \\
\text { - Coordinator/Manager: keeps the group on task } \\
\text { - Timekeeper: keeps track of time allotted for assignment } \\
\text { - Secretary/Recorder: writes down group responses } \\
\text { - Evaluator: keeps notes on group processing and social skills } \\
\text { - Encourager: makes sure all group members have their turns } \\
\text { - Reader: reads directions, problems, and resource materials for group }\end{array}$ & & $\sqrt{ }$ \\
\hline
\end{tabular}


- Checker: checks group members' comprehension of material to be learned or discussed

- Encourager: provides positive feedback to group members

- Go-for: leaves his or her seat to run group errands.

The preceding roles should be assigned based on the nature of learning tasks and should be rotated so that all learners will have an equal chance to practice different roles.

\begin{tabular}{lll}
\hline 4. The teacher gives class presentation to present the material. & $\sqrt{ }$ \\
\hline 5. $\quad \begin{array}{l}\text { a. The teacher gives each group one worksheet. } \\
\text { b. The teacher asks students to complete the task according to the rules: } \\
\text { - Students have responsibility to make sure that their teammates have } \\
\text { learned the material. }\end{array}$ & $\sqrt{ }$ \\
- No one is finished studying until all teammates have mastered the \\
subject.
\end{tabular}

Based on Table 3, the procedure of STAD which was not implemented by ETR was in point 3 , where the teacher should assign a role for each member of the groups. Later from the interview, he justified that his reason for not doing so was because he wanted each group to take full responsibility by making decisions on their own for their roles (see E3 or excerpt number 3 in the following interview section). Furthermore, the explanation of the five procedures with few modifications is as follows.

In point $1 \mathrm{c}$, the quiz sheet should be given one copy for each student, but ETR read the quiz aloud instead of distributing it to the students. He did this modification because he found it helpful to monitor the students while doing individual quiz, in which after every question of the quiz, he had the chance to walk around the class to observe their work. He considered this to be more efficient as it helps avoid cheating during the quiz.

In point $1 \mathrm{~d}$, an answer key for the quiz should be given one copy for each group, but ETR wrote all the answers on the white board. He explained that distributing copies of the answer key was not possible due to financial problems of the school (see E1 or excerpt number 1 in the following interview section). There are limitations for teachers in distributing printed or photocopied papers for classroom tasks; that is why most teachers in his school rely on textbooks provided by the ministry of education for schools. Nonetheless, ETR asked each student to correct the quiz by switching his/her answer sheet with their nearest student and the answer was written by him directly on the white board. 
In point 1e, the teacher should provide a team recognition form such as proposed by Slavin (1995). However, ETR did modification on the team recognition form because the scoring system was not based on the improvement points as proposed by Slavin (1995) but by ETR himself. ETR determined the scoring for the answers and among the five groups, the group that reached the highest score was rewarded as the super team. Three groups that reached the scores below them were rewarded as the great team, and the least score was rewarded as the good team.

In brief, the teacher did not use one procedure as suggested by Shaaban and Ghaith (2005) and five procedures with few modifications as explained above. However, during the observation, ETR showed good qualification as a classroom manager. Despite the class was noisy at times, he was seen firm in quieting them down. He moved from one group to another, making sure that they were working cooperatively. He had organized the students, time, and material efficiently. He controlled the class orderly and paid good attention in monitoring the students' activities.

\section{Interview}

The result of interview revealed that ETR often implemented STAD as one of the techniques in teaching reading. But it did not mean that he was continuously implementing STAD, as stated in E1. It may be due to the material and the learning goal; therefore, he applied a variety of techniques to achieve the learning goal with appropriate materials. Financial problem was also one of rationale for ETR to use other techniques or modify them since some techniques require many documents (e.g. papers and photocopies for materials, as explained in the previous section). Additionally, repeated similar technique may also bore his students.

(E1) I mostly use...ah...STAD technique in teaching reading to my students...although I do not use every time I come to class because there are other techniques. Some techniques also require money that the school cannot always provide...so I have to consider that, too...I modify in accordance to the situation.

In applying STAD technique, ETR grouped the students into heterogeneous groups mixed among the level of achievement and gender. It is in line with Borich (2007) who explained that STAD is a cooperative type of class management that divides students into four or five members of learning teams. They are mixed in performance level, gender, achievement and others. As explained in E2 and E3:

(E2) The groups are heterogeneous...there are students which have high level achievement and which also have low level achievement...they are mixed...including different gender. I choose the members for the groups because I know their ability...ah...so they can work effectively...the high level and low level achievement students help each other.

(E3) I group the students...mixing among students that high level achievement, with students who have low level achievement...ya...the students who have average level achievement included...even though we have to assign roles to students, I leave this responsibility to them so they will be accountable for their own group work.

ETR used STAD in teaching reading because it provided opportunities for the students to be more active because they focus on group learning activities such as discussion, in which they cooperate, assist, and have responsibility towards each other (see E4 and E5). 
(E4) STAD is one of the strategies in teaching reading...ah...for making the students to be more active... ah ... because they work in a group.

(E5) And the students which have high level achievement will help the students who have low level achievement...then the students who have low level achievement can also ask question to the students who have higher level achievement.

The procedures in STAD also requires the teacher to appoint roles to students in their group (see Table 3), however, in this case ETR believed that this duty should be executed by the group members themselves to strengthen unity as a group. Moreover, Gross (1991) also said that STAD is a technique that is effective to increase students' motivation, enthusiasm, and develop responsibility (see E6 and E7).

(E6) They can work together, can motivate students with low level achievement...these students are motivated by seeing the activity of their friends who are very active...so they will follow to be active, follow to give input, follow to hear so they can work together...then if they do not understand, they can ask their friends in the group who know more than them.

(E7) I think STAD technique can also motivate the students...can make students to be more enthusiasm in learning...perhaps students who have low level achievement may be motivated by seeing the students with high level achievement... who are busy answering questions in a task by the teacher...such as, ah, searching for the meaning of the vocabulary from discussion or the dictionary, so, (these high level achievement students) can motivate others to follow ... to try.

Additionally, in E8, ETR illustrated that STAD technique promoted student centeredness, in which the interactions were not only between teacher-student but also between studentstudent (Slavin, 1995). Eggen and Kauchak (2001) argued that the teachers in STAD classes are as facilitators in assisting students to achieve the learning goals. The interaction between student-student can be seen when they worked in group discussion to accomplish the task. Hence, discussion and knowledge sharing among members of the groups are used (Slavin, 1996).

(E8) In learning, students do not only listen to the teachers' explanation...because the students do not only listen, they also work (together).

Furthermore, in E9, ETR also indicated that STAD technique can give positive effects to the students' reading skill development; an example is an increase in vocabulary. This can be seen during the observation in the classroom by the end of the lesson in reviewing the lesson by ETR. He asked the students on the vocabulary found in the text and most of the students could answer him.

(E9) I think, indeed, teaching technique with STAD gives...ah...what we call just now...more positive responses for students. Students can increase their vocabulary...ya...increase vocabulary from words in the text which they do not know by discussing (with group members) or looking up (for meanings) in the dictionary (together).

However, besides having the benefit for the students as stated above, ETR also had some obstacles in implementing STAD technique. As explained in E10 and E11, this was because the students in his school were very heterogeneous; there were students who had high, average, low, and even very low level achievement. The ability of each student in understanding the materials were also different. 
(E10) But because the students (in my school) are very heterogeneous...it means there are clever students (high level achievement), average level achievement students, and low level achievement students... and even there are very low level achievement students. The ability to understand from each of the student is different.

(E11) For example, in a group, we may say that there are five students...four until five students...perhaps three of the students have understood but two students or one student need more explanation...while we explain again, three of the students (who have understood) can get bored... and if I do not explain it (again) to the two students, they may never understand. (It is) a little obstacle for students who have low level of proficiency.

To solve the problem mentioned in E10 to E11, ETR was required to be more attentive particularly to students with low and very low level achievements individually. He had to explain the lesson repetitively until they understood his explanation (see E12). This can be seen during the observation in the classroom when he participated as a co-participant in a particular group that was held back in accomplishing their work due to one or two students who had difficulty in carrying out the task. This was because of their lacked of understanding of the task and had very low proficiency in English.

(E12) To solve this problem...it requires me to be close to the student individually...I have to explain it again and again to him/her, repeatedly, so that he/she finally understands, more or less.

In E13, ETR also added that those students who needed special attention from teachers were also asked to be assisted by other members in their group.

(E13) They should get special attention from us (teachers) and I also ask the group to explain to him (who does not understand) carefully...we (as teachers) should help him, but he should gain understanding from his friend first before we move in.

The action described in E13 may help students who are reluctant, nervous, and afraid or lack confidence when confronted by a teacher. Facing peers or those more conversant to them may be less intimidating compared to facing the teacher (Achmad and Yusuf, 2014).

\section{DISCUSSION AND CONCLUSION}

From this study, we found that in implementing STAD technique, the teacher did not conduct one procedure and modified five procedures based on the theory by Shaaban and Ghaith (2005). The procedure not used was assigning a role for each member of the groups by the teacher. He wanted each group to decide their own roles to further increase their responsibility towards each other. However, from our observation, we find that this procedure is quite necessary to avoid stronger students with higher level achievement discourage or overwhelm weaker students with lower level achievement (Achmad and Yusuf, 2014). It is true that by having the students decide on their roles, it can raise their awareness of duty in their group. Nevertheless, if the teacher did know their individual characteristics in the class, we believe that it would be better for him to assign the roles to make the group work more timely instead of having the students make their own decisions for this part, especially since they are still quite young (i.e. junior high school). Perhaps the noisy class situation at times was due to their adolescence and that is why we reckon that this could be lessened if the teacher had assigned roles for each of them. They would likely be more precautious when the instruction of roles came from the teacher. 
Furthermore, the other five procedures that were modified by the teacher were found to be due to efficiency, time limitation, and the school's financial problem. For example, to provide the quiz sheet and the answer sheet for every student in the class for every time he used STAD was not possible since the school was not able to provide such facility to every class. In should be noted that financial problems are not just faced by his school, but typically by most Indonesian public schools as well (see Yasin and Yusuf, 2014). And so, to suit with the current situation that he was in, he deemed the modifications to be worthy.

Nonetheless, STAD technique is considered suitable to be implemented in teaching reading to EFL learners. Based on the results of the interview, despite the students in the school being very heterogeneous in their levels of achievement, the teacher found this technique to be a good alternative solution in teaching a large class with mixed level of achievements because they have a good chance of learning from each other especially in developing their vocabulary. Furthermore, the students did not only get a chance of gaining explanation from the teacher, but also from their friends in their own group. This indicated that this technique promoted student centered learning, in which the interactions were not only between teacher-student, but also between student-student.

Even though there were limitations in this study (e.g. the data was only collected from one teacher teaching to only one class), we believe that this study can contribute in some ways or another to the development of language education by adding knowledge to the existing literature on STAD technique in the EFL context. Furthermore, it is also important to note that the teachers' knowledge on their self-belief and attitude do contribute in producing an effective teaching with fulfilling outcomes. Therefore, it is recommended that other researchers conduct further interviews on this topic by considering a larger group of respondents and further in-depth observation of more classroom meetings.

\section{REFERENCES}

Achmad, D. \& Yusuf, Y. Q. (2014). Observing Pair-Work Task in an English Speaking Class. International Journal of Instruction, 7(1): 151-164.

Alijanian, E. (2012). The Effect of Student Teams Achievement Division Technique on English Achievement of Iranian EFL learners. Theory and Practice in Language Studies, 2(9): 1971-1975.

Borich, G. D. (2007). Effective Teaching Methods: Research-Based Practice, $\left(6^{\text {th }}\right.$ Ed.). Upper Saddle River, NJ: Pearson Merrill Prentice Hall.

Burns, A. (1999). Collaborative Action Research for English Language Teachers. Cambridge: Cambridge University Press.

Cahyani, I., M. (2013). The Effect of Student Teams Achievement Division (STAD) on Student's Reading Comprehension Ability. Jurnal Penelitian, Pendidikan dan Pembelajaran, 1(1): 177-183.

DeWalt, K. M. \& DeWalt, B. R. (2002). Participant Observation: A Guide for Fieldworkers. Walnut Creek, CA: AltaMira Press.

Eggen, P. D. \& Kauchak, D. (2001). Strategies for Teachers: Teaching Content and Thinking Skills, (4th Ed.). Boston: Allyn and Bacon.

Gross, P. (1991). Teaching Learning Activity for Students at Senior High School. London: Harper Collins Publisher. 
Harmer, J. (2007). The Practice of English Language Teaching, ( ${ }^{\text {rd }}$ Ed.). London: Pearson. Kessler, C. (Ed.). (1992). Cooperative Language Learning: A Teacher's Resource Book. Enlgewood Cliffs, NJ: Prentice Hall.

Kuzborska, I. (2011). Links between Teachers' Beliefs and Practices and Research on Reading. Reading in a Foreign Language, 23(1): 102-128.

Ningsih, S. R. J. \& Fata, I. A. (2015). Exploring Teachers' Beliefs and the Teaching Profession in Aceh. Studies in English Language and Education, 2(1): 67-78.

Nurhanifah, D. (2012). The Problems of Second Grade Students of SMPN 4 Malang in Learning English and the Efforts Made to Overcome Them. Unpublished Bachelor's thesis. Malang: English Department, State University of Malang.

Roger T. \& Johnson, D. W. (1994). An Overview of Cooperative Learning. In J. Thousand, A. Villa \& A. Nevin (Eds.), Creativity and Collaborative Learning (pp. 31-44). Baltimore: Brookes Press.

Shaaban, K. \& Ghaith, G. (2005). The Theoretical Relevance and Efficacy of Using Cooperative Learning in the ESL/EFL Classroom. TESL Reporter, 38(2): 14-28.

Slavin, R. E. (1994). Educational Psychology: Theory into Practice, (4th Ed). Boston: Allyn and Bacon.

Slavin, R. E. (1995). Cooperative Learning: Theory, Research, and Practice, (2nd Ed.). Needham Heights, MA: Allyn and Bacon.

Slavin, R. E. (1996). Research on Cooperative Learning and Achievement: What We Know, What We Need to Know. Contemporary Educational Psychology, 21(4): 43-69.

Slavin, R. E. (2010). Co-operative Learning: What Makes Group-work Work? In H. Dumont, D. Istance \& F. Benavides (Eds.), The Nature of Learning: Using Research to Inspire Practice (pp. 161-178). London: OECD Publishing.

Sousa, D. A. (2005). How the Brain Learns to Read. Thousand Oaks, CA: Corwin Press.

Wang, T. (2007). The Comparison of the Difficulties between Cooperative Learning and Traditional Teaching Methods in College English Teachers. The Journal of Human Resource and Adult Learning, 3(2): 23 - 30.

Warawudhi, R. (2012). English Reading Achievement: STAD vs. Lecture Method for EFL Learners. Journal of Institutional Research South East Asia, 10(1): 5-24.

Woolley, G. (2011). Reading Comprehension: Assisting Children with Learning Difficulties. New York: Springer.

Yasin, B. \& Yusuf, Y. Q. (2014). The Policy Outcomes and Feasibility of School-Based Management in Aceh. Asia Pacific Journal of Educational Development, 3(1): 21-32.

\section{Turkish Abstract}

\section{Bir Öğretmenin Öğrenci Takımları-Başarı Bölümleri Tekniği Öğretim Deneyimi}

$\mathrm{Bu}$ çalışma öğrenci takımları-başarı bölümleri yöntemini nitel bir yaklaşım kullanarak okuma becerisini öğrencilerinde başarılı olarak ilerleten bir öğretmeni gözlem ve görüşme teknikleriyle incelemiștir. $\mathrm{Bu}$ yöntemin uygulamasındaki ortaya çıkıș Shaaban ve Ghaith'in (2005) prosedürleridir ve ögretmenin bu yöntemi kullanmasındaki duruşunu belirlemek amacıyla bir 
görüşme yapılmıştır. Uygulama sırasındaki gözlemler sonucunda öğretmen grubun herbir üyesine bir rol yükleyen tekniği kullanmadığ gözlemlenmiştir. Görüşmede öğretmen bu prosedürü uygulamamasının sebebini rol biçmenin grup görev başarısında bir sorumluluk duygusunu yükseltmesi olarak belirlemiştir. Dahası, öğretmen orjinal dokuz prosedürün beşinde değişiklik yapmıştır. Değişiklikler öğrencileri verilen quizlerin yöntemi, basılı cevap anahtarı verme, öğrencilerin quizlerini düzeltme yöntemi, takım belirleme formunu verme, ve öğrenci başarısını belirleme yolları üzerindedir. Değişikliklerin sebebi olarak öğretmen öğrencilerin yeterliklerini, zaman kısıtlamasını ve okulun finansal problemlerini söylemiştir.

Anahtar Kelimeler: öğrenci takımları-başarı bölümleri (STAD), STAD prosedürleri, grup çalışması, İngilizce okuma dersi, öğretmen duruşu

\section{French Abstract}

L'expérience d'un Professeur dans Enseignement avec Division d'Accomplissement d'équipes d'Étudiant (STAD) Technique

Cette étude regarde la Division d'Accomplissement d'équipes d'Étudiant (STAD) la mise en œuvre d'une approche qualitative en observant et interviewant un professeur qui a avec succès amélioré l'accomplissement de lecture de ses étudiants EFL avec cette technique. Les procédures par Shaaban et Ghaith (2005) étaient la base pour la mise en œuvre STAD et une interview a été fait pour exposer la position du professeur envers l'utilisation de STAD. Basé sur notre observation pendant son enseignement dans une classe lisante en mettant en œuvre STAD, il a été trouvé qu'il n'a pas mis en œuvre une procédure de cette technique, qui assignait un rôle pour chaque membre des groupes. De l'interview, il a informé qu'il n'a pas conduit cette procédure parce qu'il a cru que l'assignation de rôles devrait être confiée aux étudiants pour augmenter leur sens de responsabilité vers l'accomplissement de la tâche de groupe. En outre, il a aussi modifié cinq procédures de neuf procédures de STAD proposé par Shaaban et Ghaith (2005). Les procédures modifiées ont été liées à la façon que l'on a donnée au questionnaire aux étudiants, fournissant la clé de réponse imprimée, les façons de corriger le questionnaire(quiz) de l'étudiant, fournissant le formulaire de reconnaissance d'équipe et les façons de reconnaître l'accomplissement des étudiants. Il a informé qu'ils ont été modifiés en raison de l'efficacité d'étudiants, la limitation de temps et le problème financier de l'école.

Mots Clés: division d'accomplissement d'équipes d'étudiant, les procédures de STAD, travail en groupe, EFL lecture de classe, la position de professeur

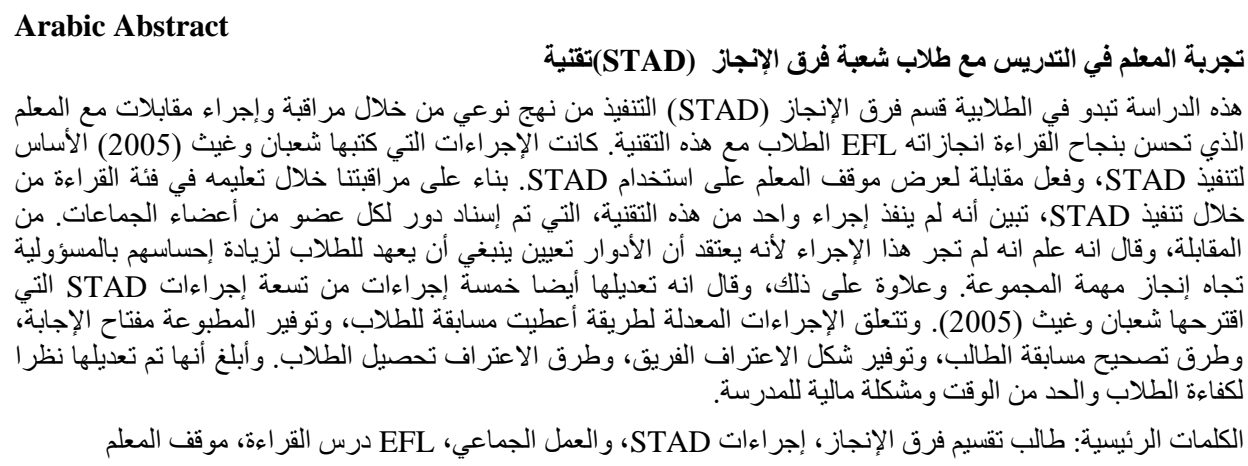

